\title{
Freezing nucleation apparatus puts new slant on study of biological ice nucleators in precipitation
}

\author{
E. Stopelli ${ }^{1}$, F. Conen ${ }^{1}$, L. Zimmermann ${ }^{1}$, C. Alewell ${ }^{1}$, and C. E. Morris ${ }^{2}$ \\ ${ }^{1}$ Dept. Environmental Sciences, University of Basel, Switzerland \\ ${ }^{2}$ INRA, UR0407 Pathologie Végétale, 84143 Montfavet Cedex, France \\ Correspondence to: E. Stopelli (emiliano.stopelli@unibas.ch) \\ Received: 11 September 2013 - Published in Atmos. Meas. Tech. Discuss.: 24 October 2013 \\ Revised: 3 January 2014 - Accepted: 6 January 2014 - Published: 14 January 2014
}

\begin{abstract}
For decades, drop-freezing instruments have contributed to a better understanding of biological ice nucleation and its likely implications for cloud and precipitation development. Yet, current instruments have limitations. Drops analysed on a cold stage are subject to evaporation and potential contamination. The use of closed tubes provides a partial solution to these problems, but freezing events are still difficult to be clearly detected. Here, we present a new apparatus where freezing in closed tubes is detected automatically by a change in light transmission upon ice development, caused by the formation of air bubbles and crystal facets that scatter light. Risks of contamination and introduction of biases linked to detecting the freezing temperature of a sample are then minimized. To illustrate the performance of the new apparatus we show initial results of two assays with snow samples. In one, we repeatedly analysed the sample (208 tubes) over the course of a month with storage at $+4{ }^{\circ} \mathrm{C}$, during which evidence for biological ice nucleation activity emerged through an increase in the number of ice nucleators active around $-4{ }^{\circ} \mathrm{C}$. In the second assay, we indicate the possibility of increasingly isolating a single ice nucleator from a precipitation sample, potentially determining the nature of a particle responsible for a nucleation activity measured directly in the sample. These two seminal approaches highlight the relevance of this handy apparatus for providing new points of view in biological ice nucleation research.
\end{abstract}

\section{Introduction}

Certain particles suspended in the atmosphere provide surfaces for nucleating ice in rising and cooling air masses. These small activated ice fractions can enlarge through the Wegener-Bergeron-Findeisen process of accretion by water vapour deposition. Secondary processes of collision and collection then may lead to the formation of ice fragments sufficiently large to fall and develop into precipitation. The only naturally occurring particles active at temperatures warmer than $-12{ }^{\circ} \mathrm{C}$ are mainly biological ice nucleators (IN) (Murray et al., 2012), such as bacteria and parts thereof. Their potential to facilitate precipitation is still under debate, particularly their impact on global or on regional scales (Möhler et al., 2007; Hoose et al., 2010; Morris et al., 2011). Bacteria are in fact minor constituents of aerosols, moreover only a fraction of them is capable of ice nucleation activity. However, in the temperature window between -3 and $-8^{\circ} \mathrm{C}$ a process of ice multiplication through splintering (Hallett and Mossop, 1974) can effectively multiply a very small number of initial ice particles $\left(<10 \mathrm{~m}^{-3}\right)$ and lead to the full glaciation of supercooled cumulus clouds (Mason, 1996).

All these open questions are part of a recent "resurgence in ice nuclei measurement research" (DeMott et al., 2011), where measurements at temperatures above $-12^{\circ} \mathrm{C}$ are clearly a remaining research issue. The objectives of that research are to quantify reliably the abundance of IN in the air that are active above $-12^{\circ} \mathrm{C}$, to obtain information on their temporal dynamics, on their sources, on the environmental factors determining their numbers, and on the scale of their influence (Möhler et al., 2007; DeMott and Prenni, 2010; Morris et al., 2011). 
Different instruments have been developed to assess the concentration of IN in the atmosphere and to study their behaviour. Cloud chambers have seen substantial improvements in recent decades (DeMott et al., 2011), but there has not been the same progress with drop freeze instruments. These instruments are the only ones that can be used to estimate the very small numbers of IN in environmental samples active at temperatures warmer than $-10^{\circ} \mathrm{C}$. Typically, a sample (melted snow, rain or cloud water, impinger liquid with trapped aerosol) is divided into aliquots in the form of small drops on plates or larger aliquots in tubes. These are then allocated in a cooling bath where temperature decreases over time. The temperature of nucleation of each drop is recorded through direct observation of increased turbidity due to freezing of the water sample. Probably the most widely used instrument of this kind is the one described by Vali and Stansbury (1966), which continues to provide new insights into freezing nucleation at temperatures above $-15^{\circ} \mathrm{C}$ (e.g. Vali, 1995, 2008; Attard et al., 2012; Joly et al., 2013). Drop freeze assays provide no sharp discrimination among all classes of IN present in a sample and on microscale mechanisms of freezing. However, they allow the analysis of larger quantities of samples (typically 1-10 mL) than microfluid instruments $\left(0.065 \mathrm{~mL} \mathrm{~h}^{-1}\right.$; Stan et al., 2009), and this at cooling rates similar to those in slowly ascending clouds $\left(<1 \mathrm{~m} \mathrm{~s}^{-1}\right)$ where precipitation is initiated by the formation of ice crystals $\left(<1^{\circ} \mathrm{C} \mathrm{min}^{-1}\right)$. The cumulative number $K_{(\theta)}$ of IN active at a temperature $\theta$ present in a unit volume of the sample can thus be calculated (Vali, 1971), considering the total number of drops/tubes analysed, $N_{\mathrm{T}}$, the number of unfrozen ones at a certain temperature, $N_{\theta}$, and the volume analysed, $V$ :

$K_{(\theta)}=\frac{\left[\ln N_{\mathrm{T}}-\ln N_{\theta}\right]}{V}$

The major limitations of testing drops on a cold stage are the potential evaporation of the droplets over time, their contamination from the surrounding air and the risk of crosscontamination of drops on the plate through ice growth among the drops or splintering. When these problems are overcome by putting the drops into closed tubes, new challenges emerge. One is the difficulty of detecting freezing in a closed tube. For that purpose, tubes are usually taken out of the cold bath after a relevant temperature change and inspected visually across their radial axis, where ice formation leaves visible traces of entrapped gas or solutes ("milky" appearance of tube content, or part thereof). Problems hereby are that condensation on the outside of the supercooled tube may be mistaken for frozen content and that removal from the cold bath temporarily increases the tube temperature.

Here, we present a new freezing apparatus that overcomes these problems. It is equipped with an automatic detection system for nucleation events, based on the reduction of light transmission upon freezing of a liquid sample. We present the example of an assay conducted with this new apparatus that would not have been possible to achieve with previous instruments and, in addition, we describe another interesting application that could be realized with it in the future.

\section{Description of the apparatus (LINDA)}

The core of the LINDA (LED-based Ice Nucleation Detection Apparatus) device is a $7 \times 8$ array of red LEDs (645 nm wavelength), surface mounted on a printed circuit board cast into a polycarbonate housing $(128 \times 113 \times$ $10 \mathrm{~mm}$, Fig. 1b) and submersed in a cold bath (Lauda RC6, Lauda-Königshofen, Germany). A total of 52 sample tubes (0.5 mL Eppendorf Safe-Lock) containing each between 40 and $400 \mu \mathrm{L}$ of liquid sample are held in another polycarbonate plate (Fig. 1b) and placed onto the LED array so that each tube is vertically centered on an LED. Four sample tubes with cast-in $\mathrm{Pt}_{1000}$ temperature sensors are placed in the corner positions of the tube holder (Fig. 1c). A USB CMOS Monochrome Camera (DMK 72BUC02, The Imaging Source Europe GmbH, Bremen, Germany) mounted in a black hood placed above the sample array is directed toward the lids of the tubes, which are illuminated from below (Fig. 1a). Images are recorded every six seconds. Light intensity in the area of each tube lid is extracted from each image and recorded into a text file together with the temperature at the time the image was taken. Further analysis of the data collected can be easily done with little effort through a spreadsheet to obtain the very precise freezing temperature for each tube allocated in the cooling bath. More detailed technical information on hardware and software components is available at the website: http://azug.minpet.unibas. ch/ lukas/FNA/index.html.

The apparatus was devised based on the principle that the transfer of light through water is reduced upon freezing when light gets scattered by inclusions and impurities in ice, such as air bubbles, brine pockets or crystal facets (Perovich, 2003). Pure water freezes without these inclusions and impurities, so no relevant change in light transmission upon freezing is noticeable. Hence, it is essential that samples contain a small amount of salt (or buffer), which is also recommendable for reasons of sample stability and to avoid eventual osmotic stress on living cells. To see whether the addition of small amounts of salt has a noticeable impact on freezing temperatures, we tested fresh snow samples with and without addition of $\mathrm{NaCl}$ ( $0.9 \%$ final concentration, equal to physiological solution). Analyses were done by removing the tubes from the cold bath and inspecting them by eye. The resulting freezing spectra (Fig. 2) suggest no systematic suppression of freezing at this salt concentration. Later trials with the apparatus described in the following showed that much lower $\mathrm{NaCl}$ concentrations $(0.11 \%)$ were already sufficient for reliably detecting change in light transmission.

The phase change from liquid to ice is clearly detectable by a sudden decrease in transmitted light (Fig. 3). It is not 

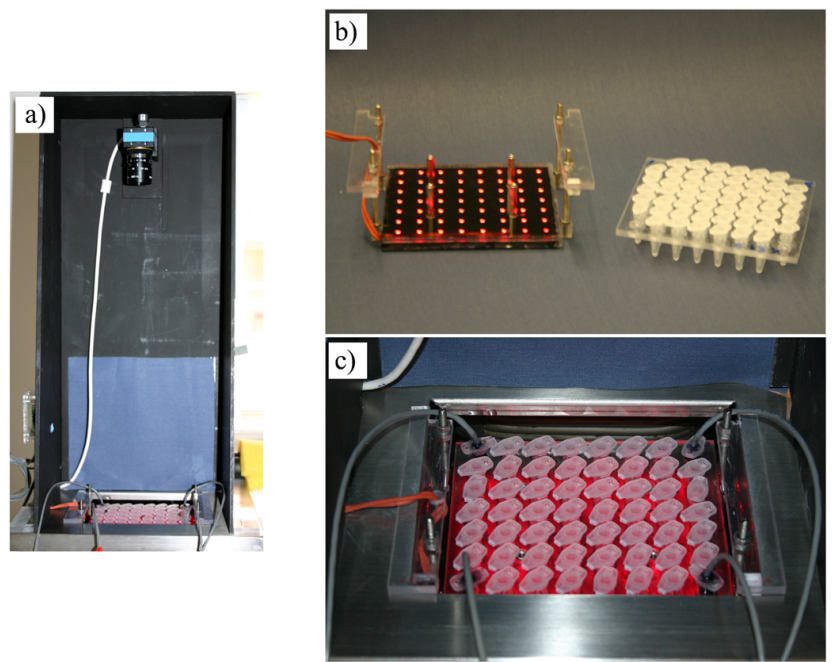

Fig. 1. (a) Cold bath set-up, ready for analysis with camera recording from above; (b) LED array and polycarbonate plate holding 52 sample tubes; (c) detail of tubes and $\mathrm{Pt}_{1000}$ sensors in the corners of the grid inside the cooling bath.

necessary to have identical light intensities for each tube at the beginning of an analysis, since freezing is determined by the relative change in light intensity and not by its absolute value. The upper limit for the number of IN detectable is determined by the total number of aliquots analysed (52) and the smallest volume that still results in a clearly detectable change in light transmission when changing from liquid to frozen $(40 \mu \mathrm{L})$. In a given sample it is $98.8 \mathrm{IN} \mathrm{mL}^{-1}$ $((\ln (52)-\ln (1)) / 0.04 \mathrm{~mL})$, but can be extended by orders of magnitude through proper dilution. The part of the tube containing the sample is still fully surrounded by cooling liquid when containing a sample of $400 \mu \mathrm{L}$, which can be considered the largest volume for the analysis. This provides for a lower detection limit of $0.05 \mathrm{IN} \mathrm{mL}^{-1}((\ln (52)-$ $\ln (51)) / 0.4 \mathrm{~mL}$ ). For the operational conditions described from here on, the background due to container characteristics, water quality and working environment could become an issue at temperatures around $-15^{\circ} \mathrm{C}$ or lower. The employment of other methods based on different materials and smaller volume quantities is then recommended to investigate colder temperature intervals, simultaneously allowing the detection of higher abundance of ice nucleators with a reduced background (for instance, Iannone et al., 2011).

Pure substances with a known freezing temperature range were tested to assess the repeatability in the detection of nucleation events. For this purpose we repeated five times the analysis of the same array of 52 tubes containing $200 \mu \mathrm{L}$ of sample each. Samples tested were montmorillonite (at the concentration of $50 \mu \mathrm{g} \mathrm{mL}^{-1}$ ) and $\operatorname{SNOMAX}^{\circledR}\left(0.1 \mu \mathrm{gL}^{-1}\right)$, showing a freezing temperature range from $-7.1^{\circ} \mathrm{C}$ to $-13.0^{\circ} \mathrm{C}$ (median $-11.9^{\circ} \mathrm{C}$ ) and from $-4.3{ }^{\circ} \mathrm{C}$ to $-5.4{ }^{\circ} \mathrm{C}$ (median $-5.0^{\circ} \mathrm{C}$ ), respectively.

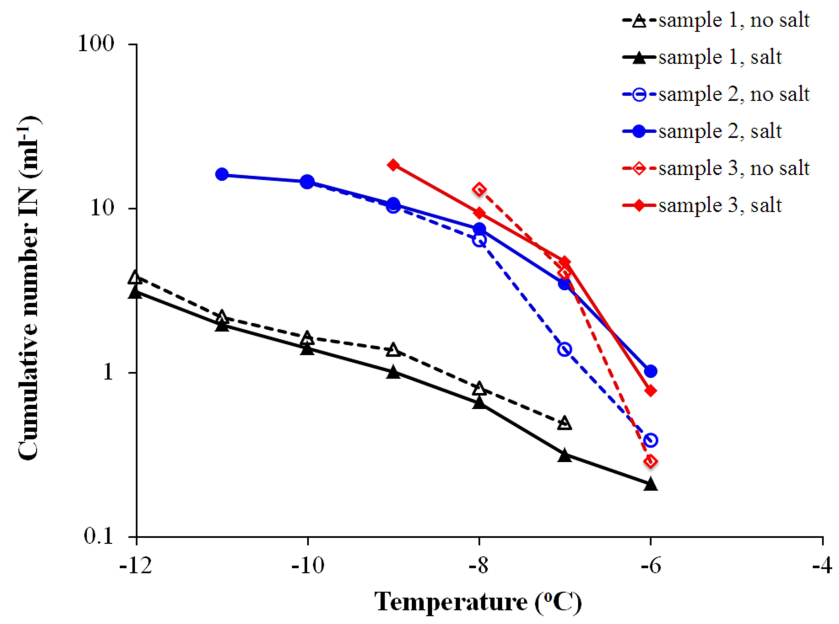

Fig. 2. Paired snow water samples without (open symbols) and with (closed symbols) $\mathrm{NaCl}(0.9 \%)$. Each spectrum based on manual/visual analysis of 54 tubes at $200 \mu \mathrm{L}$.

For both substances, the median value of the standard deviation in freezing temperatures of repeatedly frozen individual tubes was $0.20^{\circ} \mathrm{C}$, comparable to the value reported in Vali (2008) for a soil suspension. This standard deviation in repeated analyses is a combination of the precision of the apparatus and the stochastic element in freezing nucleation. Hence, we can say that the precision of the apparatus ( 1 standard deviation) must be smaller than $0.2^{\circ} \mathrm{C}$.

\section{New applications}

This section illustrates two kinds of freezing nucleation assays that are facilitated by use of the described apparatus. It is intended as an outlook on opportunities. The first example makes use of the possibility to store and repeatedly analyse the same sample without risk of contamination or evaporation. The second example demonstrates how the sample may be recovered after freezing analysis for other subsequent characterization.

\subsection{Evolution of a sample upon storage at low temperature}

In the first example, we follow the dynamics of biological IN in a snow sample over several weeks. Ice nucleators active at temperatures warmer than $-10^{\circ} \mathrm{C}$ in precipitation samples are efficiently deactivated by heat through boiling and to some extent by the addition of lysozyme, an enzyme that partially destroys the microbial cell wall. This has led to the conclusion that ice nuclei in environmental samples are associated with microbial cells (Christner et al., 2008). Here, we try to approach the same issue, but from the opposite direction. Effectively, certain conditions are known to activate the ice nucleating property of bacterial cells. Modifications 


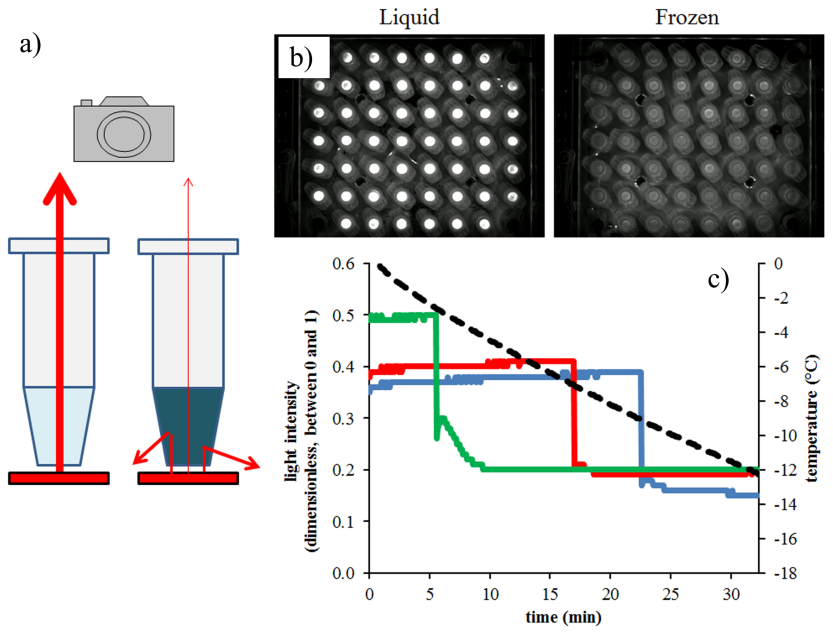

Fig. 3. (a) Schematic representation of the principle of freezing detection by a decrease in light transmission associated with the passage from liquid water (light blue) to ice (dark blue); (b) images taken by the camera at the beginning and the end of a test run when all samples were liquid (left panel) and frozen (right panel); (c) time record of temperature (black dashed line) and light intensities of three tubes (coloured solid lines) showing the sudden and sharp decrease in recorded light intensity (full line), associated with ice nucleation. As shown in the graph, this system provides good detection of freezing events without loss of reliability also at temperatures close to $0^{\circ} \mathrm{C}$, where visual detection may be more difficult (Vali, 1995).

in temperature and nutrient supply lead to the aggregation of individual IN proteins on the outer cell membrane into larger units able to catalyse freezing at warmer temperatures than before (Nemecek-Marshall et al., 1993; Ruggles et al., 1993). Hence, if active IN cells are present in a sample of snow water, which is naturally poor in nutrients, aggregation of IN proteins into larger units may be stimulated during storage at a cool temperature and result in an onset of freezing at increasingly warmer temperatures with time.

To test this assumption, snow was collected on 22 January 2013 from an open field in the northern part of the Jura mountains $\left(47^{\circ} 28^{\prime} 30^{\prime \prime} \mathrm{N}, 07^{\circ} 40^{\prime} 07^{\prime \prime} \mathrm{E}, 700 \mathrm{~m}\right.$ a.s.l.) in Switzerland, where it had accumulated the night before in a powdery layer $(4 \mathrm{~cm})$ on top of an older, frozen snow layer. The snow was melted at room temperature and divided into 4 aliquots. Different quantities of $9 \% \mathrm{NaCl}$ solution were added to each aliquot $(0.11 \%, 0.23 \%, 0.45 \%$, and $0.9 \%$ as final salt concentrations). Aliquots were then divided into 52 tubes at $200 \mu \mathrm{L}$ each and analysed with the apparatus, at a cooling rate of $0.4^{\circ} \mathrm{C} \mathrm{min}-1$. A blank sample of 52 tubes of pure water with $\mathrm{NaCl}$ added $(0.9 \%)$ was treated in the same way but did not show a single freezing event throughout the trial. To determine the dynamics of IN activity of the samples over time, freezing assays were conducted at increasing time intervals. Between freezing assays, the samples were stored at $+4{ }^{\circ} \mathrm{C}$. Since no differences were observed among salt concentrations, we pooled the data for further analysis,
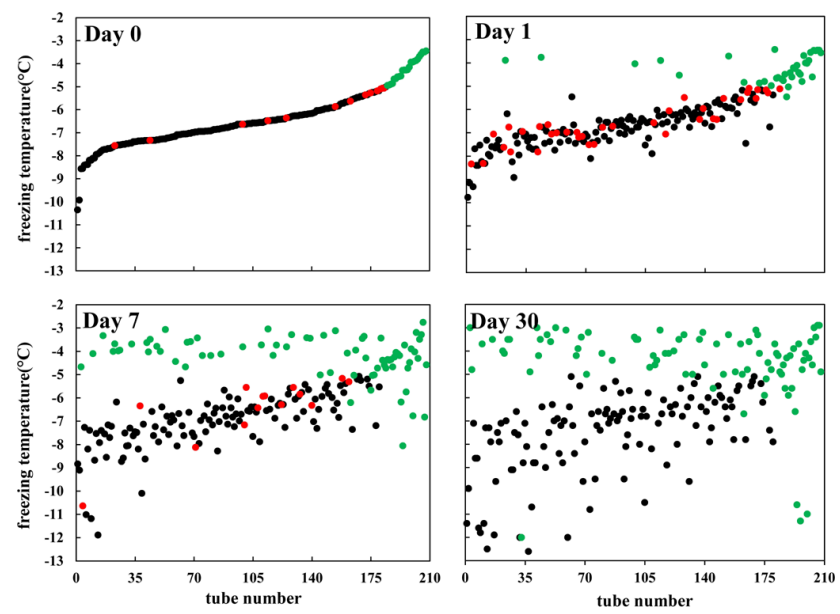

Fig. 4. Evolution of freezing temperature of 208 tubes filled with $200 \mu \mathrm{L}$ of snow water and stored at $+4{ }^{\circ} \mathrm{C}$. Tubes were analysed on the day of snow sampling (day 0 ) and 1,7 , and 30 days later. They were ranked by freezing temperatures on day 0 and this rank was allocated as a tube identity number for the rest of the trial. Freezing temperatures were determined between $0{ }^{\circ} \mathrm{C}$ and $-12{ }^{\circ} \mathrm{C}$. Points were coloured according to different behaviours of associated tubes: black for those not frozen at or above $-5^{\circ} \mathrm{C}$ and not doing so the next time they are analysed; red for those not frozen at or above $-5^{\circ} \mathrm{C}$, but which do so the next time they are analysed; green for those frozen at or above $-5^{\circ} \mathrm{C}$ during the current or one of the previous analyses.

resulting in a total of 208 observed tubes. Freezing temperatures were approximately normally distributed among the tubes on the day of sampling (Fig. 4, day 0). When analysed the following day, $90 \%$ of the tubes froze within a range of $\pm 0.7^{\circ} \mathrm{C}$ of the temperature at which they had frozen the previous day. However, 13 tubes which had frozen at lower temperatures during the first analysis, subsequently froze at $-5^{\circ} \mathrm{C}$ or warmer after one day (Fig. 4 , signed as red dots on day 0 and as green dots from day 1 on). After one week, 37 new tubes moved into this temperature range, while after one month 14 tubes still showed this increase (Fig. 4, red dots), suggesting the appearance of more active IN over time. On the other hand, in some tubes IN started to lose efficiency, thus leading to a lower temperature of freezing (Fig. 4, green dots progressively decreasing towards colder temperatures).

The results seem to correspond to what is expected according to the aggregational model for microbial IN proteins, in particular they suggest the likely active aggregation of small subunits into larger structures effectively catalysing ice formation at warmer temperatures and a parallel disaggregation of medium-sized structures into smaller, less efficient IN. A multiplication of IN active cells seems unlikely, because the total number of IN active at $-12{ }^{\circ} \mathrm{C}$ had actually declined (Table 1) and freezing cycles may have reduced the viability of cells. Observing a sample over longer time could thus provide compelling evidence for the presence and number of living biological ice nucleators. 
Table 1. Development of IN in snow water over 30 days during storage at $4{ }^{\circ} \mathrm{C}$. To observe the development, the same 208 sample tubes were repeatedly subjected to freezing tests. The lower limit of detection in this trial was 0.03 , the upper limit was $27.80 \mathrm{IN} \mathrm{mL}^{-1}$. The number of IN active at $-4{ }^{\circ} \mathrm{C}$ quadruplicated, while the number of IN active at $-8^{\circ} \mathrm{C}$ halved (indicated in italic).

\begin{tabular}{rrrrrrr}
\hline & \multicolumn{6}{c}{ Cumulative number of ice nucleators $\left(\mathrm{mL}^{-1}\right)$} \\
\cline { 2 - 7 }$T\left({ }^{\circ} \mathrm{C}\right)$ & day 0 & day 1 & day 3 & day 7 & day 15 & day 30 \\
\hline-3 & & & & 0.05 & & 0.15 \\
-4 & 0.26 & 0.42 & 0.47 & 0.99 & 0.47 & 1.05 \\
-5 & 0.67 & 0.99 & 1.27 & 2.02 & 1.84 & 2.33 \\
-6 & 1.99 & 2.17 & 2.25 & 3.41 & 3.00 & 3.51 \\
-7 & 5.98 & 6.14 & 5.45 & 6.83 & 4.72 & 5.90 \\
-8 & 15.31 & 14.86 & 11.70 & 12.20 & 8.85 & 8.72 \\
-9 & 24.19 & 22.08 & 22.08 & 18.47 & 13.04 & 11.03 \\
-10 & 27.80 & & 27.80 & 19.42 & 15.31 & 13.04 \\
-11 & & & 27.80 & 24.19 & 18.47 & 14.86 \\
-12 & & & 27.80 & & 22.08 & 22.08 \\
\hline
\end{tabular}

\subsection{Progressive isolation of ice nucleators from a sample}

In a second application, we demonstrate how the sample may be recovered after freezing analysis for other subsequent characterization and in particular to progressively isolate an IN active at temperatures above $-12^{\circ} \mathrm{C}$ from an environmental sample. To demonstrate this, a fresh snow sample was collected in March 2013 from a rooftop in Basel. The snow was melted at room temperature, $\mathrm{NaCl}$ was added to a final concentration of $0.9 \%$ and analysis of the sample was carried out to a minimum temperature of $-8^{\circ} \mathrm{C}$ after it had been divided into 52 tubes at $200 \mu \mathrm{L}$ each. The five tubes (from here on called samples 1 to 5 , Table 2) that had frozen first were further topped up, after they had melted, with $0.9 \% \mathrm{NaCl}$ (in pure sterile water) to a total volume of $500 \mu \mathrm{L}$ and split into 10 portions (tubes) at $50 \mu \mathrm{L}$ for a second freeze test. From each series of 10 tubes, the tube that froze first was topped up to $500 \mu \mathrm{L}$ and split into 10 tubes at $50 \mu \mathrm{L}$ for further analysis. The same scheme was followed until a fourth dilution step. Handling was carried out in cold conditions $\left(0-5^{\circ} \mathrm{C}\right)$. In a series of blank samples ( 52 tubes at $50 \mu \mathrm{L}$ filled with the $0.9 \% \mathrm{NaCl}$ solution used to top up) none of the tubes froze at $-10^{\circ} \mathrm{C}$ or warmer. In two out of the five samples the putative initial ice nucleator could be followed to a dilution of $10^{-4}$ (Table 2). In the other three cases ice nucleators either shifted their onset of freezing to temperatures colder than $-8^{\circ} \mathrm{C}$ or were completely lost. This loss may be due either to an incomplete recovery of all particles present in a tube or to the manipulating conditions destroying the ice nucleation active sites. Improvement of this methodology to optimize IN recovery is currently under study.

Snow samples previously collected in Basel during winter showed a total number of bacteria (epifluorescence microscopy, SYBR green staining) ranging from $10^{3}$ to
Table 2. Freezing temperatures of five samples $(200 \mu \mathrm{L}$ each of the same snow water) repeatedly diluted $(1: 10$ with $0.9 \% \mathrm{NaCl})$ and split into ten portions each. A freeze test was performed after the first dilution step and the freezing temperature is indicated for those of the ten sub-samples that froze at temperatures warmer than to $-8{ }^{\circ} \mathrm{C}$. Only the sub-sample with the warmest freezing temperature was taken to the next dilution step (marked in italic). Those freezing at colder temperatures were discarded. A total of 4 dilution steps were carried out.

\begin{tabular}{|c|c|c|c|c|c|}
\hline \multirow[b]{3}{*}{ Sample } & \multicolumn{5}{|c|}{ Dilution step } \\
\hline & 0 & 1 & 2 & 3 & 4 \\
\hline & \multicolumn{5}{|c|}{ Freezing temperature $\left({ }^{\circ} \mathrm{C}\right)$} \\
\hline 1 & -5.0 & -7.5 & -7.9 & -8.0 & \\
\hline 2 & -5.4 & $\begin{array}{l}-6.0 \\
-6.3 \\
-7.3 \\
-7.4\end{array}$ & $\begin{array}{l}-6.5 \\
-6.9\end{array}$ & -6.5 & -6.5 \\
\hline 3 & -5.6 & $\begin{array}{l}-6.8 \\
-7.2 \\
-7.7\end{array}$ & -7.0 & & \\
\hline 4 & -5.7 & $\begin{array}{l}-5.6 \\
-7.1 \\
-7.2\end{array}$ & -5.8 & -5.9 & -6.1 \\
\hline 5 & -5.9 & $\begin{array}{l}-6.7 \\
-7.2 \\
-7.7\end{array}$ & -6.6 & & \\
\hline
\end{tabular}

$10^{5}$ cells $\mathrm{mL}^{-1}$ of melted snow. Through four dilution steps, so by a factor of $10^{4}, 1$ to 10 bacterial cells remained in the last series of dilution and the solution also included the most active IN. Thus, this sequential isolation can help to reduce the background of the non-ice nucleation active microbial community in the sample and provides a first step towards an identification of most active IN. At that stage, either selective cultivation-based methods may allow the recovery of the biological agent responsible for the nucleation, or molecular approaches such as amplification of key genes may be applied, since extraction and amplification of DNA even from single cells seems to become an increasingly feasible method (Gao et al., 2011).

\section{Conclusions}

We have developed the traditional immersion freezing nucleation method further by detecting the phase change from liquid to ice in closed test tubes through the reduction of light transmission upon freezing. The change in signal upon freezing is abrupt and clear. Manipulation of the sample before and during analysis is minimised, parameters of analysis can be accurately controlled, reliably recorded and risk of contamination is negligible, even during prolonged storage. 
This extends the possibilities of traditional immersion freezing tests. One interesting new application is the possibility of detecting the presence of living biological ice nucleators in a sample by storing it at low temperatures and observing over the course of days or weeks an increase in the number of IN active around $-4{ }^{\circ} \mathrm{C}$. Moreover, it could be possible to recover and isolate warm IN directly from a sample with known nucleating activity through subsequent dilution steps during which the number of particles not active as IN is successively reduced from a sample. Thus, this new apparatus could help to bridge the gap between the analysis of environmental samples collected in field and laboratory assays in ongoing and future research on biological ice nucleation.

Acknowledgements. The work reported here was supported by the Swiss National Science Foundation (SNF) through grant number 200021_140228.

Edited by: P. Herckes

\section{References}

Attard, E., Yang, H., Delort, A.-M., Amato, P., Pöschl, U., Glaux, C., Koop, T., and Morris, C. E.: Effects of atmospheric conditions on ice nucleation activity of Pseudomonas, Atmos. Chem. Phys., 12, 10667-10677, doi:10.5194/acp-12-10667-2012, 2012.

Christner, B. C., Morris, C. E., Foreman, C. M., Cai, R., and Sands, D. C.: Ubiquity of biological ice nucleators in snowfall, Science, 319, 1214, doi:10.1126/science.1149757, 2008.

DeMott, P. J. and Prenni, A. J.: New directions: need for defining the numbers and sources of biological aerosols acting as ice nuclei, Atmos. Environ., 44, 1944-1945, doi:10.1016/j.atmosenv.2010.02.032, 2010.

DeMott, P. J., Möhler, O., Stetzer, O., Vali, G., Levin, Z., Petters, D. M., Murakami, M., Leisner, T., Bundke, U., Klein, H., Kanji, A. Z., Cotton, R., Jones, H., Benz, S., Brinkmann, M., Rzesanke, D., Saathoff, H., Nicolet, M., Saito, A., Nillius, B., Bingmer, H., Abbatt, J., Ardon, K., Ganor, E., Georgakopoulos, D. G., and Saunders, C.: Resurgence in ice nuclei measurement research, B. Am. Meteorol. Soc., 92, 1623-1635, doi:10.1175/2011BAMS3119.1, 2011.

Gao, W., Zhang W., and Meldrum, D. R.: RT-qPCR based quantitative analysis of gene expression in single bacterial cells, J. Microbiol. Meth., 85, 221-227, doi:10.1016/j.mimet.2011.03.008, 2011.

Hallett, J. and Mossop, S.: Production of secondary ice particles during the riming process, Nature, 249, 26-28, 1974.

Hoose, C., Kristjánsson, J. E., and Burrows, S. M.: How important is biological ice nucleation in clouds on a global scale?, Environ. Res. Lett., 5, 1-7, doi:10.1088/1748-9326/5/2/024009, 2010.
Iannone, R., Chernoff, D. I., Pringle, A., Martin, S. T., and Bertram, A. K.: The ice nucleation ability of one of the most abundant types of fungal spores found in the atmosphere, Atmos. Chem. Phys., 11, 1191-1201, doi:10.5194/acp-11-1191-2011, 2011.

Joly, M., Attard, E., Sancelme, M., Deguillame, L., Guilbaud, C., Morris, C. E., Amato, P., and Delort, A. M.: Ice nucleation activity of bacteria isolated from cloud water, Atmos. Environ., 70, 392-400, doi:10.1016/j.atmosenv.2013.01.027, 2013.

Mason, B. J.: The rapid glaciation of slightly supercooled cumulus clouds, Q. J. Roy. Meteorol. Soc., 122, 357-365, 1996.

Möhler, O., DeMott, P. J., Vali, G., and Levin, Z.: Microbiology and atmospheric processes: the role of biological particles in cloud physics, Biogeosciences, 4, 1059-1071, doi:10.5194/bg-4-10592007, 2007.

Morris, C. E., Sands, D. C., Bardin, M., Jaenicke, R., Vogel, B., Leyronas, C., Ariya, P. A., and Psenner, R.: Microbiology and atmospheric processes: research challenges concerning the impact of airborne micro-organisms on the atmosphere and climate, Biogeosciences, 8, 17-25, doi:10.5194/bg-8-17-2011, 2011.

Murray, B. J., O’Sullivan, D., Atkinson, J. D., and Webb, M. E.: Ice nucleation by particles immersed in suprcooled cloud droplets, Chem. Soc. Rev., 41, 6519-6554, doi:10.1039/C2CS35200A, 2012.

Nemecek-Marshall, M., LaDuca, R., and Fall, R.: High-level expression of ice nuclei in a Pseudomonas syringe strain is induced by nutrient limitation and low temperature, J. Bacteriol., 175, 4062-4070, 1993.

Perovich, D. K.: Complex yet translucent: the optical properties of sea ice, Physica B, 338, 107-114, doi:10.1016/S09214526(03)00470-8, 2003.

Ruggles, J. A., Nemecek-Marshall, M., and Fall, R.: Kinetics of appearance and disappearance of classes of bacterial ice nuclei support an aggregation model for ice nucleus assembly, J. Bacteriol., 175, 7216-7221, 1993

Stan, C. A., Schneider, G. F., Shevkoplyas, S. S., Hashimoto, M., Ibanescu, M., Wiley, B. J., and Whitesides, G. M.: A microfluidic apparatus for the study of ice nucleation in supercooled water drops, Lab Chip, 9, 2293-2305, doi:10.1039/B906198C, 2009.

Vali, G.: Quantitative evaluation of experimental results on the heterogeneous freezing nucleation of supercooled liquids, J. Atmos. Sci., 28, 402-409, 1971.

Vali, G.: Principles of ice nucleation, in: Biological ice nucleation and its applications, American Phytopathological Society; edited by: Lee Jr., E. R., Warren, G. J., and Gusta, L. V., APS Press, St. Paul, Minnesota, USA, 1-28, 1995.

Vali, G.: Repeatability and randomness in heterogeneous freezing nucleation, Atmos. Chem. Phys., 8, 5017-5031, doi:10.5194/acp-8-5017-2008, 2008.

Vali, G. and Stansbury E. J.: Time-dependent characteristics of the heterogeneous nucleation of ice, Can. J. Phys., 44, 477-502, 1966. 